\title{
Empowering Youth through HIV/AIDS Program in Indonesia
}

\author{
Sondang Ratnauli Sianturi \\ Sint Carolus School of Health Sciences Jakarta, Indonesia \\ Jalan Salemba Raya Nomor 41, Jakarta Pusat, 10440 \\ Corresponding author: sondangrsianturi@gmail.com
}

\begin{abstract}
Background: HIV/AIDS problem remains a concern in the Sustainability Development Goals program with the highest in youth. The cause of HIVIAIDS on youth because of the lack of information and understanding about gender and reproductive health. Objectives: This study aims to analyze the implementation of programs related to HIV/AIDS among youth in Jakarta, Indonesia. Method: The method is used mixed methods research with an explanatory design. The sample consisted of 155 youth and 6 informants. This study uses Structural Equation Modelling (SEM) to analyze the data and to give information about which variable that can influence. This study took place in Jakarta Timur and Jakarta Pusat, the ethical approval come from the local major. Results: The results of a bivariate analysis mostly respondents have a good knowledge about HIV/AIDS both transmission and prevention; but attitude (54\%) and action (60\%). The multivariate analysis by SEM using 8.71 Lisrel obtained that the knowledge, attitudes, and actions are simultaneous may affect each other which indicates that knowledge has a great influence on the actions and attitudes of respondents to the prevention of HIV/AIDS. Conclusion: All programs that are already running well, just based on the results of research programs and activities undertaken is not yet complete and comprehensive information on the young target. The study recommends the monitoring of adolescents, especially youth so that we can stop cases of HIV/AIDS on the younger generation.
\end{abstract}

Keywords: HIV/AIDS Programs, Evaluation, Empowering, Youth

\section{INTRODUCTION}

Some countries discussed a program and agreement that the issue of HIV/AIDS included in the achievement of the Sustainability Development Goals (SDGs) by 2017 (Biati, 2014). The achievement of the SDGs is the responsibility of all components of the nation.Today, the development of the HIV/AIDS epidemic in Indonesia is the fastest in Southeast Asia. Data from the Ministry of Health obtained HIV/AIDS cases up to July 2014 as many as 35,341 young patients, most in the ratio of 20-29 years of age was 17,941 (Adiaksa, 2011).These data suggest that youth are an important target, as seen from the nature of youth (Fadhilla \& Kusumastuti, 2010).

The most experienced by youth is caused by the use of non-sterile syringes, drugs, which is used simultaneously by drug users and heterosexuals. There was also a lack of information and understanding ofyouthabout gender and reproductive health to be the main entrance and at risk for HIV/AIDS (Baptiste, et al, 2005; Baptiste, et al, 2006). With so many people living with HIV/AIDS in Indonesia, prevention should focused to youth between 20 and 29 years. Comprehensive prevention efforts need to be done by involving all relevant sectors, especially the young people who represented the groups concerned with AIDS. So new cases can be suppressed. Studies of HIV/AIDS and youth in Indonesia 
are carried out by various institutions in Indonesia during the past 10 years (2004-2014), found that the infection rate of HIV/AIDS among the productive age is increasing. In Jakarta $80 \%$ of teens ages $15-24$ years have had sexual intercourse before marriage with a partner of their age. (Biati, 2014).

Activities on HIV/AIDS has been done at the school in the form of curriculum and through health centers that can reach youth in the region, but the results have not been up. Suryadi (2004) stated that the lack of active participation of youth in national development, an issue which will be addressed through the implementation of various development programs which related policy. The strategy used in carrying out the contruction is done by enhancing the role of society including youth empowerment, institutional strengthening, improved coordination between sectors and institutions. HIV/AIDS prevention programs need to be done jointly, starting from the family, schools and the health center (Jennings, et al, 2006). The main problem today is the lack of effort in youth empowerment who empowering others. Youth as one of the potential of resources in the area of the underutilized community are in the development process (Ziff, et al, 2006). There is a program which is aimed and can reach by youth. The program performs education and counseling with peer counselors, but the implementation of this program is not very effective because youth do not know how to solve the probloem and how to refer the case into health center. Hence the need for an activity or program is that can reach young people who are not in school is needed. This can be done by empowering young people in the form of youth in their respective areas like giving education, training and making good relationship with youth.

Community based HIV/AIDS prevention is an important issue that must be implemented with the involvement of community health centers, family, and youth organization. Prevention through the empowerment of young people through youth organization in each region is expected to reduce the number of chances of getting HIV/AIDS and the deviant behavior of theyouththemselves. Based on the background described above, the researchers are interested in analyzing the implementation of policies relating to the empowerment of youth in tackling HIV/AIDS in Central Jakarta.

\section{METHOD}

This study used a quantitative method with the explanatory design to form clusters involving 155 urban youth samples at the age of 18-25 years in Central Jakarta and 6 informants. This study used questionnaire related to HIV/AIDS which are 20 questions about transmission, 20 questions about prevention, 19 questions about attitude and 19 questions about action. This study also did by interview with 6 informants who are youth, and community leader. The analysis data is used structural equation modeling (SEM) with Lisrel 8.71 to get a more powerful influence between the variables.

Research Ethics in this study are the right of respondents to respect privacy, the right to guarantee the cinfidentiality of information provided, right to obtain security or safety as a result of the information provided and the obligation of researchers to maintain the privacy of respondents, ensuring confidentiality of information, and is responsible for the security and safety of the respondents for the information provided. Confidentiality is maintained by researchers. The anonymity of respondents and the data is guaranteed by the researcher. After all the research is completed, researchers will save the data and destroy it after three years. 


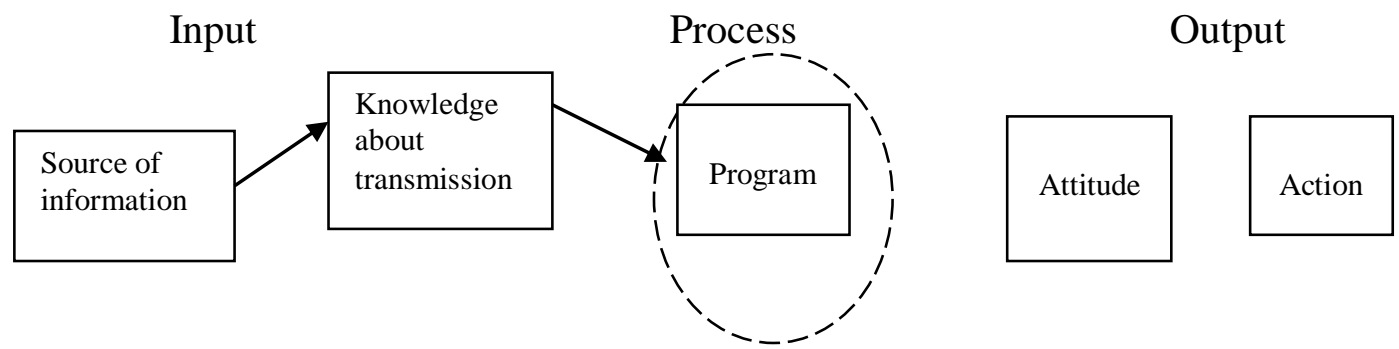

Figure 1 Research framework that guides this research

\section{RESULTS AND DISCUSSION}

Researchers used quantitative research with a qualitative explanatory design that aims to explain the programs that run among youth. This study used a questionnaire about the level of knowledge and attitudes towards HIV/AIDS. Researchers believe that by knowing information about HIV/AIDS intact theyouthhave been getting information from health officials to run the program associated with HIV/AIDS.

Table 1 Characteristic of respondent

\begin{tabular}{|c|c|c|}
\hline \multirow{2}{*}{$\begin{array}{ll} & \text { Characteristics } \\
\text { Female } & \end{array}$} & 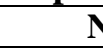 & $\%$ \\
\hline & 69 & $44.5 \%$ \\
\hline Male & 86 & $55.5 \%$ \\
\hline \multirow{2}{*}{$\begin{array}{l}\text { High School } \\
\text { University }\end{array}$} & 86 & $55.5 \%$ \\
\hline & 69 & $44.5 \%$ \\
\hline \multirow{2}{*}{$\begin{array}{l}\text { Get information from electronic media } \\
\text { Get information from people }\end{array}$} & 104 & $67.1 \%$ \\
\hline & 47 & $30.3 \%$ \\
\hline Good Knowledge & 129 & $83.2 \%$ \\
\hline Bad Knowledge & 26 & $16.8 \%$ \\
\hline
\end{tabular}

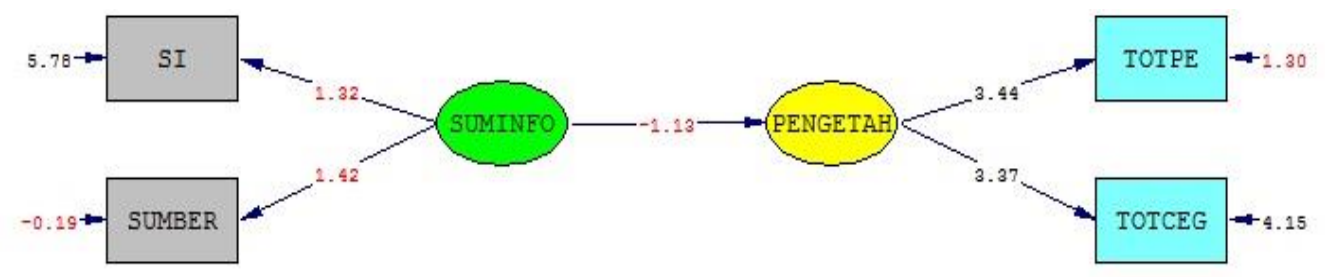

Chi-9quare $=0.16, d f=1, \mathrm{p}-\mathrm{value}=0.68830, \mathrm{RMSER}=0.000$

Figure 2 Relationship between the source of information with knowledge about transmission and prevention (Lisrel 8.71).

The results showed that respondent gets information is from electronic media, indicated by the value of -1.13 multiple with a rate of $95 \%$. While the coefficient of determination adjusted (Adjusted $\mathrm{R}^{2}$ ) of 0.051 showed no significant relationship. Adjusted $\mathrm{R}^{2}$ with a value of $5.1 \%$ indicates that the resources of a person have very little effect on a person's knowledge about HIV/AIDS. Based on qualitative results showed that youth get information on counseling, a peer support group/peer educator and NGOs down to the region and there are three informants who have not received any information at all regarding HIV/AIDS (Ziff, et al, 2006). 


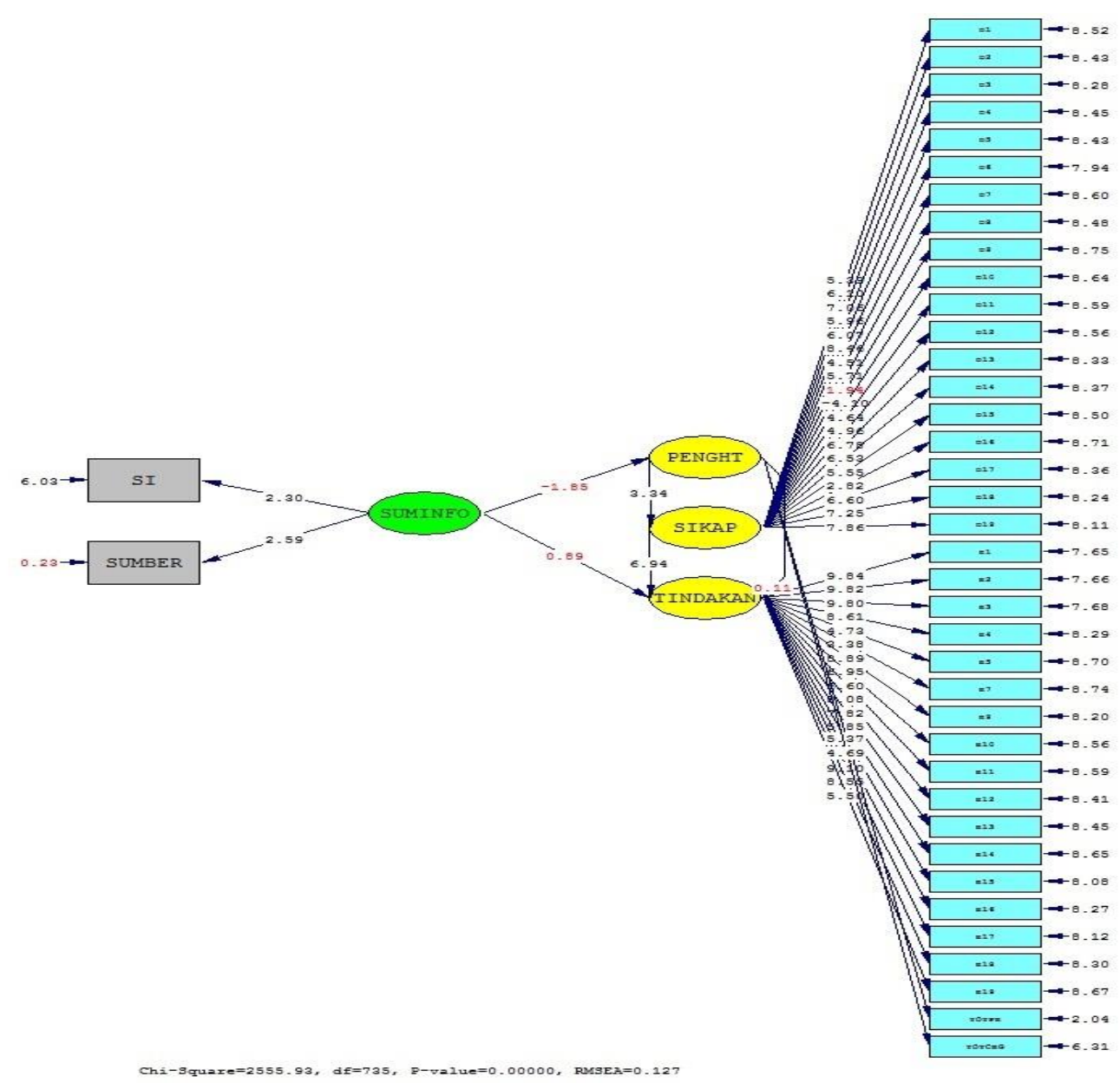

Figure 3 Multivariate analysis between knowledge, attitude, and action (see also in appendix)

Structural Equation Modelling is also conducted three activities that check the validity and reliability of the instrument (factor analysis confirmatory, like the one in Fig. 3 ), the test model of the relationship between variables and obtain a useful model for prediction. The coefficient of determination adjusted (Adjusted $\mathrm{R}^{2}$ ) was 0.71 (with a value of error $=0.0010$ ) showed no significant influence of knowledge, attitudes, and actions. The adjusted $\mathrm{R}^{2}$ value of $71 \%$ indicates that the knowledge possessed by a person had an enormous influence on the attitudes and eventually will be shown in the action/behavior of people on the prevention of HIV / AIDS.

This study uses the theory about precede-proceed as the conceptual framework. Proceed-precede theory emphasizes the input, process, and output, where is input from youth, information, policy, and to monitor and evaluate the program (Sulistiawan, et al, 2014). Referring to the national policy, DKI Jakarta has had the regulation that HIV/AIDS is a dedicated program. HIV/AIDS programs related to youth in Jakarta is that sexual transmission prevention program (behavior, condom promotion, management of STI and VCT), transmission syringe (behavioral, LISS, PTRM, VCT, drug treatment and condom promotion), transmission from mother to baby, the provision of blood transfusions are safe, universal precautions, post-exposure prophylaxis; Program Care, support and treatment that VCT services, Periodic Inspection CD4, ARV treatment, and prevention and treatment of opportunistic infections; Program to mitigate the impact of HIV/AIDS that is context- 
dependent economic empowerment as well as program development and management of quality assurance programs (Jennings, et al, 2006; Ziff, et al, 2006).

Programs that are already running well, based on the results of research programs and activities is not yet complete and comprehensive information on the young target. Most youth who gain information and knowledge about HIV/AIDS do not know and understand in depth how prevention and actions they need to do (Sulistiawan, et al, 2014). Based on the results of qualitative data obtained that the informant said that the activities carried out to youth need to be made as forms of coaching life skill of how to defend themselves from the temptation given and addressing existing problems, but it is also the need for activities that are more applicable to the teenagers about HIV/AIDS (Sudikno, Simanungkalit, \& Siswanto, 2010). This can be achieved by a process of empowerment by using activities more applicable and in accordance with the interests of youth.

This study has limitations are the youth was very little in number means that they busy with their schools and their activities. This is because youth who active in youth organization is not much, so the researchers had difficulty in retrieving data, and when researchers took data into the region, occurred inequities program and the information provided to the youth. From four regions in Jakarta, researchers have shown that HIV/AIDS programs did not go well.

\section{CONCLUSION}

HIV and AIDS epidemic is growing rapidly and younger age groups. HIV/AIDS epidemic emerged and spread through the behavior of adolescents, irregularities gay and heterosexual promiscuity and intravenous drug abuse. So from the results of this study obtained data is that there is no significant relationship between sex, education, resources with the level of knowledge, attitudes, and actions. Whereas with a good knowledge and properly it can support the attitudes and actions on the prevention of HIV/AIDS is also good. On the other hand, the existing program does not run on the lowest level that teens in the community. Health care providers should collaborate with relevant NGOs to reach out and provide information about HIV/AIDS to young people in the community.

\section{REFERENCES}

Adiaksa, F. P. (2011). Program terapi kreatif sebagai upaya penguatan diri orang dengan HIV/AIDs (ODHA) di Yayasan Pelita Ilmu Tebet Jakarta Selatan.

Baptiste, D. R., Paikoff, R. L., McKay, M. M., Madison-Boyd, S., Coleman, D., \& Bell, C. (2005). Collaborating with an urban community to develop an HIV and AIDS prevention program for black youth and families. Behavior Modification. 29(2), 370416.

Baptiste, D. R., Bhana, A., Petersen, I., McKay, M., Voisin, D., Bell, C., \& Martinez, D. D. (2006). Community collaborative youth-focused HIV/AIDS prevention in South Africa and Trinidad: preliminary findings. Journal of pediatric psychology. 31(9), 905-916.

Biati, Y. Y. B. (2014) .Pemberdayaan Pemuda Melalui Kegiatan Karang Taruna Di Desa Bongohulawa Kecamatan Bongomeme (Doctoral dissertation, Universitas Negeri Gorontalo).

Fadhilla, A \& Kusumastuti. (2010) .Hubungan antara pengetahuan dengan sikap seksual pranikah remaja. Karya tulis ilmiah. Fakultas kedokteran Universitas Sebelas Maret. 
Jennings, L. B., Parra-Medina, D. M., Hilfinger-Messias, D. K., \& McLoughlin, K. (2006). Toward a critical social theory of youth empowerment. Journal of Community Practice. 14(1-2), 31-55.

Mprah, W. K. (2013). Exploring Knowledge and Attitudes Towards HIV/AIDS among Deaf People in Ghana. dcidj, 22-38.

Nawawi,H.Ismail. (2009). Public Policy. Surabaya: PMN, Surabaya.

Nugroho, Riant.(2011). Public Policy. Jakarta: PT Elex Komputindo.

Oktarina. (2009). Hubungan antara karakteristik responden, keadaan wilayah dengan pengetahuan, sikap terhadap HIV/AIDS pada masyarakat Indonesia. Buletin Penelitian Sistem Kesehatan. Vol 12(4): 362-369.

RI, P. P. K. S. K., \& Jenderal, I. K. K. S. (2012).Aku bangga aku tahu: Pedoman pelaksanaan kampanye HIV dan AIDS pada kaum muda usia 15-24 tahun.

Sudikno, Simanungkalit, B., \& Siswanto. (2010). Pengetahuan HIV dan AIDS pada Remaja di Indonesia (Analisis data Riskesdas 2010). Pusat teknologi intervensi kesehatan masyarakat.

Sulistiawan, D., Hakim, L., Mahenda, A. R., Bikatofani, R. R., \& Ibad, M. (2014). Revitalisasi Peran Karang Taruna Sebagai Komunitas Penggerak Antimadat dan Seksbebas (Kompas) Remaja di kawasan Lokalisasi Dolly, Surabaya. Program Kreativitas Mahasiswa-Pengabdian Kepada Masyarakat.

Suryana, B., \& Abral. (2012). Teacher's Perception and The Role in HIV/AIDS Prevention. Vokasi, 172-183.

Ziff, M. A., Harper, G. W., Chutuape, K. S., Deeds, B. G., Futterman, D., Francisco, V. T., ... \& Ellen, J. M. (2006). Laying the foundation for Connect to Protect®: A multi-site community mobilization intervention to reduce HIV/AIDS incidence and prevalence among urban youth. Journal of Urban Health. 83(3), 506-522. 